\title{
TINGKAT VALIDITAS MEDIA PEMBELAJARAN KIMIA BERBASIS ANDROID
}

\section{VALIDITY OF ANDROID-BASED CHEMISTRY LEARNING MEDIA}

\author{
Nina Adriani*, Ardi Widhia Sabekti \\ Program Studi Pendidikan Kimia, Universitas Maritim Raja Ali Haji \\ Jl. Politeknik Senggarang, Tanjungpinang, Kepulauan Riau 29115 \\ *e-mail korespondensi: nina.adriani@umrah.ac.id
}

\begin{abstract}
Abstrak
Media pembelajaran adalah satu hal penting dalam proses belajar mengajar. Pemanfaatan teknologi masa kini seperti android menjadi salah satu pilihan dalam meningkatkan kualitas pembelajaran. Penelitian ini bertujuan untuk mengetahui tingkat kelayakan dari media pembelajaran berbasis android yang digunakan dalam mata kuliah kimia hidrokarbon. Metode penelitian menggunakan model pengembangan 4D yang terdiri dari empat tahapan, yaitu pendefinisian (define), perancangan (design), pengembangan (develop) dan penyebaran (disseminate). Namun, dalam penelitian ini, hanya dilakukan tiga tahapan saja hingga tahap pengembangan (develop). Tingkat kelayakan diketahui dengan mengukur validitas menggunakan angket yang disebar kepada dua orang validator ahli. Hasil validitas media menunjukkan nilai 3,45 dan persentase sebanyak $86,25 \%$, sedangkan validitas materi dengan nilai 3,18 dengan persentase sebanyak 79,68\%. Sehingga dapat disimpulkan bahwa media pembelajaran kimia berbasis android yang dikembangkan sudah layak untuk diujicobakan kepada pengguna.
\end{abstract}

Kata Kunci: android, kelayakan, media pembelajaran

\begin{abstract}
Learning media is an important thing in the teaching and learning process. The use of technology today such as Android is one of the options in improving the quality of learning. This study aims to determine the level of feasibility of Android-based learning media used in hydrocarbon chemistry courses. The research method uses 4D development model which consists of four stages, namely define, design, develop and disseminate. However, in this study, only three stages were carried out until the development stage. The level of feasibility is known by measuring validity using a questionnaire distributed to two expert validators. The results of media validity showed a value of 3.45 and a percentage of $86.25 \%$, while the material validity with a value of 3.18 with a percentage of $79.68 \%$. So that it can be concluded that the Android-based chemistry learning media developed is feasible to be tested on users.
\end{abstract}

Keywords: android, validity, learning media

\section{PENDAHULUAN}

Media memiliki peran penting dalam pembelajaran, karena tanpa media proses belajar mengajar tidak berjalan lancar (Widiadi, 2016). Alat komunikasi mobile tidak hanya sebatas telepon atau chatting saja, tetapi sekarang sudah dapat digunakan untuk mengakses internet dengan sistem operasi android (Sukmandari \& Sukardiyono, 2017). Pemanfaatan teknologi masa kini menjadi hal yang menarik bagi banyak pengguna, terutama mahasiswa yang hampir seluruhnya sudah menggunakan smartphone yang berbasis android. Penggunaan media android sudah mulai banyak digunakan khususnya dalam pembelajaran, dimana proses belajar mengajar dapat menggunakan smartphone sebagai alat komunikasi (Sabekti \& Adriani, 2018). Penggunaan media android untuk menerapkan materi pengajaran berbentuk digital sehingga mencapai tujuan daya saing nasional akan menggantikan pembelajaran secara tradisional (Lin dkk., 2017). 
Pendidik juga dituntut untuk menciptakan lingkungan yang kondusif guna meningkatkan proses belajar mengajar yang efektif dan efisien (Mulyasa, 2008). Selain itu belajar akan terasa lebih menarik karena tidak hanya sekedar buku ajar yang menjadi sumber pembelajaran. Media juga dapat digunakan dalam pembelajaran di dalam maupun di luar waktu belajar, karena penggunaannya yang fleksibel.

Media pembelajaran Ini sangat penting karena dapat memberikan dampak yang signifikan terhadap aktivitas mengajar di kelas. Dampaknya berkembang dari hari ke hari dan dosen serta mahasiswa terpengaruh oleh dampak karena dengan penggunaan media peserta dapat saling berdiskusi , memperkuat aktivitas kelas, mengaktifkan pembelajaran serta menciptakan kolaborasi (Hassan dkk,. 2014).

Media pembelajaran yang baik memiliki 4 faktor penting yaitu relevansi, kemudahan, kemenarikan, dan kemanfaatan (Mulyanta, 2009). Semakin relevan suatu media maka semakin menarik dan bermanfaatlah media tersebut penggunaannya. Media yang digunakan dalam proses belajar mengajar dapat menjadi alat bantu untuk mengatasi keterbatasan pendidik dalam menyampaikan materi serta keterbatasan waktu dalam mengajar (Yektyastuti \& Ikhsan, 2016).

\section{METODE PENELITIAN}

Penelitian terhadap media pembelajaran android ini dilakukan di prodi pendidikan kimia, Fakultas Keguruan dan Ilmu Pendidikan Universitas Maritim Raja Ali Haji. Penelitian dan pengembangan model 4D dipilih karena sering digunakan dalam penelitian dan pengembangan bahan ajar seperti modul, LKS dan buku ajar. Tidak terbatas pada itu saja, peneliti dapat menggunakan model ini untuk mengembangkan produk lain dalam hal ini media pembelajaran yang berbasis android, karena pada prinsipnya inti dari prosedur pengembangan produk sudah terwakili di sini. Perlu dipahami bahwa proses pengembangan memerlukan beberapa kali pengujian dan revisi sehingga meskipun prosedur pengembangan dipersingkat namun di dalamnya sudah mencakup proses pengujian dan revisi sehingga produk yang dikembangkan telah memenuhi kriteria produk yang baik, teruji secara empiris dan tidak ada kesalahan-kesalahan lagi (Zahroh dkk., 2014).

Mulai dari bulan April - September 2018 telah dilakukan analisis awal hingga akhirnya sampai menguji validitas media untuk mengetahui seberapa layak media android yang telah dikembangkan. Subjek penelitian terdiri dari 20 orang mahasiswa prodi pendidikan kimia yang belum pernah mengambil mata kuliah kimia hidrokarbon.

\section{Tahap Pendefinisian (Define)}

Tahap ini bertujuan untuk menetapkan dan mendefinisikan syarat-syarat pembelajaran yang membutuhkan media serta menganalisis materi yang dimasukkan ke dalam media.

a. Analisis Kurikulum

Analisis kurikulum bertujuan menjadi dasar dalam merumuskan indikator dan capaian pembelajaran serta konsep-konsep yang dikembangkan pada media.

a. Analisis Mahasiswa

Analisis mahasiswa merupakan telaah karakteristik mahasiswa yang merupakan pengguna media, meliputi analisis usia, motivasi terhadap mata kuliah, kemampuan akademik, psikomotor dan keterampilan sosial.

b. Analisis Materi

Analisis materi bertujuan untuk menentukan isi dan materi perkuliahan sebagai konsep-konsep yang dikembangkan pada media.Materi perkuliahan ditentukan berdasarkan learning outcomes yang telah dirumuskan pada kurikulum.

c. Perumusan Learning Outcomes

Perumusan learning outcomes berguna untuk merangkum hasil dari analisis konsep untuk menentukan perilaku objek penelitian.Kumpulan objek tersebut menjadi dasar untuk menyusun tes dan merancang perangkat pembelajaran yang kemudian di integrasikan ke dalam materi perangkat pembelajaran yang digunakan oleh peneliti. Adapun hasil dari tahap define ini telah dilaporkan oleh (Sabekti \& Adriani, 2018).

\section{Tahap Perancangan (Design Phase)}

Tujuan tahap perancangåan adalah untuk merancang media sesuai dengan indikator dan learning outcomes yang telah ditentukan.

\section{Tahap Pengembangan (Develop Phase)}

Sebelum media diuji terhadap mahasiswa, media yang ada divalidasi terlebih dahulu untuk menguji tingkat kelayakan. Tahap pengembangan bertujuan untuk menghasilkan media yang valid melalui Uji Validitas Media. Rancangan media yang telah dibuat dikonsultasikan dengan validator mengenai validitasnya. Validasi dilakukan oleh validator yang terdiri dari dua orang dosen. Validator ahli diminta untuk melihat kelayakan media dan kelayakan materi serta 
kebenaran konsep pembelajaran yang telah dibuat dengan memberikan kritik atau saran terhadap kekurangan yang ada pada media. Revisi dilakukan berdasarkan saran-saran yang diberikan.

Data hasil validasi media dan materi yang diperoleh, disajikan dengan menggunakan skala Likert. Cara mendapatkan kriteria tersebut menggunakan langkah sebagai berikut.

a. Rentangan skor mulai dari 1-4

b. Kriteria terbagi atas 4 tingkat, yaitu sangat valid, valid, kurang valid, dan tidak valid.

c. Rentangan skor dibagi menjadi empat kelas interval.

Penetapan tingkat validitas ditentukan menurut kriteria pada Tabel 1.

\section{HASIL DAN PEMBAHASAN}

Media yang dikembangkgaan dalam penelitian ini adalah berbasis android dengan materi kimia hidrokarbon. Kimia hidrokarbon merupakan satu mata kuliah yang mengenalkan tentang berbagai senyawa kimia organik yang
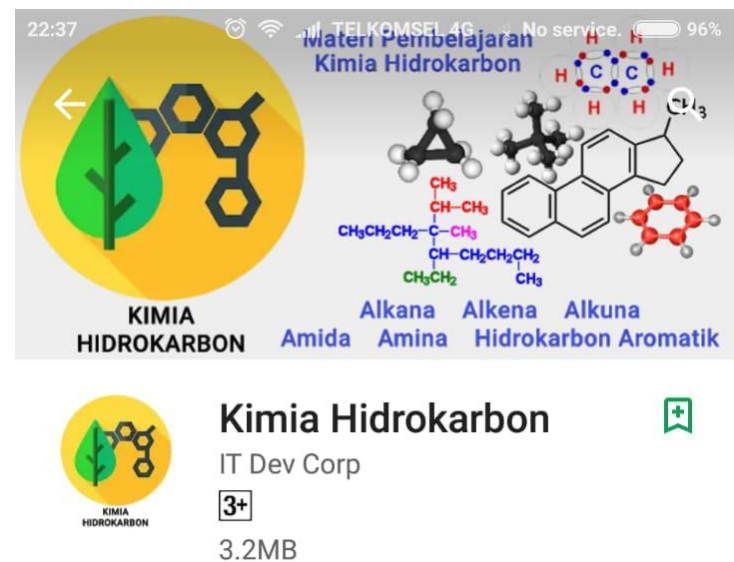

INSTALL

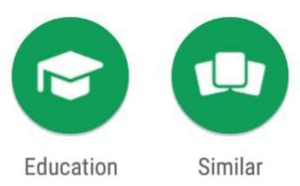

Hydrocarbon chemistry studies about

various organic chemical compounds

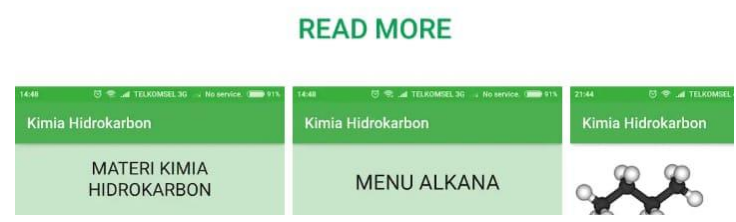

Gambar 1. Aplikasi di Playstore tersusun dari atom $\mathrm{C}$ dan $\mathrm{H}$. Media mencakup hampir keseluruhan materi kimia hidrokarbon seperti alkana, alkena, alkuna, amida, amina dan hidrokarbon aromatik. Selain penjelasan tentang materi, di dalam media juga terdapat soal latihan yang dapat dikerjakan oleh mahasiswa selesai memahami materi. Warna yang digunakan pada media juga cukup menarik dan jelas untuk digunakan. Media android ini dapat didownload dari playstore yang dihasilkan dipaparkan pada Gambar 1 dan 2.

Sebelum diuji kepada pengguna khususnya mahasiswa, media telah divalidasi terlebih dahulu oleh dua orang validator ahli yang masing-masing merupakan dosen teknik informatika yang ahli di bidang android serta dosen pendidikan kimia yang ahli di bidang pembelajaran kimia. Validasi ini dilakukan guna mengetahui tingkat kelayakan media pembelajaran android yang dikembangkan. Selanjutnya untuk hasil validasi dari segi materi dapat dilihat pada Tabel 3.

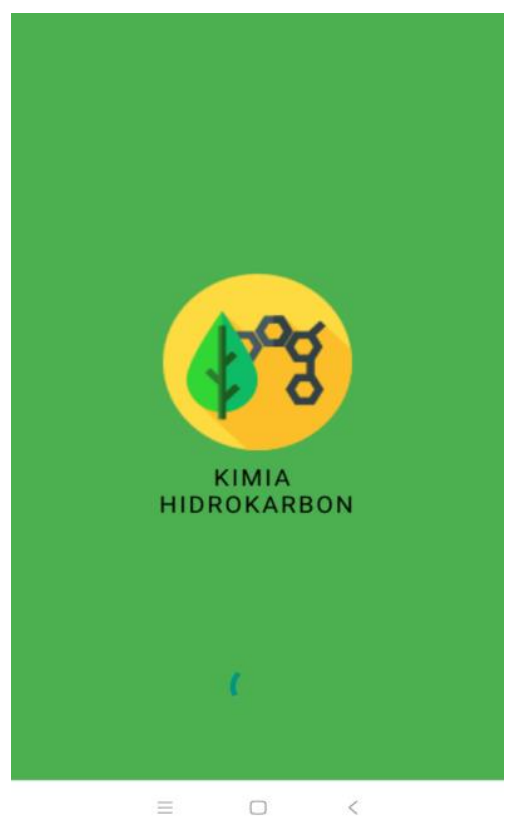

Gambar 2. Aplikasi Android Kimia Hidrokarbon

Tabel 1. Kriteria Penetapan Tingkat Validitas

\begin{tabular}{cc}
\hline Nilai validasi & Kriteria \\
\hline $1,00-1,99$ & Tidak valid \\
$2,00-2,99$ & Kurang valid \\
$3,00-3,49$ & Valid \\
$3,50-4,00$ & Sangat valid \\
\hline & (Sudjana, 2006)
\end{tabular}


Tabel 2. Hasil Validasi Media

\begin{tabular}{ccccc}
\hline \multicolumn{1}{c}{ Aspek } & Total & Rata-rata & Persentase $\%$ & Kriteria \\
\hline Kualitas tampilan & 39 & 3,25 & 81,25 & Valid \\
Rekayasa perangkat & 15 & 3,75 & 93,75 & Sangat valid \\
Keterlaksanaan & 16 & 4 & 100 & Sangat valid \\
Antarmuka & 18 & 3 & 75 & Valid \\
Kesesuaian & 13 & 3,25 & 81,25 & Valid \\
\hline \multicolumn{1}{c}{ Total } & 101 & 3,45 & 86,25 & Valid \\
\hline
\end{tabular}

Tabel 3. Hasil Validasi Materi

\begin{tabular}{lcccc}
\hline \multicolumn{1}{c}{ Aspek } & Total & Rata-rata & Persentase $\%$ & Kriteria \\
\hline Kurikulum & 12 & 3 & 75 & Valid \\
Penyajian materi & 12 & 3 & 75 & Valid \\
Evaluasi & 13 & 3,25 & 81,25 & Valid \\
Kebahasaan & 21 & 3,5 & 87,5 & Sangat Valid \\
\hline \multicolumn{1}{c}{ Total } & 58 & 3,18 & 79,68 & Valid \\
\hline
\end{tabular}

Validasi yang dilakukan oleh ahli mencakup validasi media dan materi yang memiliki beberapa kategori. Hasil validasi untuk media adalah dapat dilihat pada Tabel 2. Ada 5 kategori dalam validasi media, dimana 2 kategori seperti rekayasa perangkat dan keterlaksanaan sangat valid dan sangat layak untuk digunakan. Dari hasil validasi didapat rata-rata untuk keseluruhan kategori bidang media dengan nilai 3,45 dan persentase sebanyak $86,25 \%$. Hal ini menunjukkan bahwa media android yang digunakan telah valid dan layak diujicobakan terhadap pengguna melalui saran dan revisi terlebih dahulu dari validator ahli.

Hasil validasi dari segi materi, ada 4 kategori penilaian yang dinilai oleh validator ahli. Salah satu kategori kebahasaan mendapatkan nilai sangat valid sehingga sangat layak untuk digunakan. Hasil rata2 validasi menunjukkan nilai 3,18 dengan persentase sebanyak $79,68 \%$ menunjukkan bahwa modul sudah layak untuk digunakan dengan revisi terlebih dahulu sesuai dengan saran validator ahli.

\section{KESIMPULAN}

Media pembelajaran kimia berbasis android yang telah dikembangkan divalidasi oleh validator ahli guna mengetahui tingkat kelayakan media. Validasi terdiri dari validasi media dan materi yang terdapat dalam satu angket. Hasil validasi media menunjukkan nilai 3,45 dengan persentase sebanyak $86,25 \%$, sedangkan validasi materi menunjukkan nilai 3,18 dengan persentase sebanyak 79,68\%. Dengan demikian media android sudah layak untuk diujicobakan kepada pengguna.

\section{UCAPAN TERIMA KASIH}

Ucapan terima kasih disampaikan kepada Direktorat Riset dan Pengabdian kepada Masyarakat (DRPM) Dirjen Penguatan Riset dan Pengembangan Kemenristekdikti yang telah memberikan dukungan finansial terhadap penelitian ini.

\section{DAFTAR RUJUKAN}

Hassan, S.M., Azhar, T., Hassan, T., \& Hassan, S.H., (2014.). Using Social Media to Maximaze Students' Learning Outcames. Journal of Education and Practice. 5 (23). 157-159.

Lin, M.H., Chen, H. C., \& Liu, K.S., (2017). A Study of The Effects of Digital Learning Motivation and Learning Outcome. EURASIA Journal of Mathematics Science ang Technology Education. 13 (7). 35533564.

Mulyanta \& Leong M.M. (2009). Tutorial Membangun Multimedia Interaktif Media Pembelajaran. Yogyakarta: Universitas Atma Jaya Yogyakarta.

Mulyasa, E. (2008). Menjadi Guru Profesional Menciptakan Pembelajaran Kreatif dan 
Menyenangkan. Bandung: PT. Remaja Rosdakarya

Sabekti, A.W., \& Adriani, N., (2018). Analisis Kebutuhan Pengembangan Media Pembelajaran Berbasis Android untuk Mata Kuliah Kimia Hidrokarbon. Solo. Seminar Nasional Kimia Fisika Biologi Universitas Sebelas Maret.

Sabekti, A.W., \& Adriani, N., (2018). Pemanfaatan Teknologi Android Dalam Pembelajaran Kimia Untuk Meningkatkan Daya Saing Bangsa. Medan. SEMIRATA BKS PTN Barat Universitas Sumatera Utara.

Sudjana, N. (2006). Penilaian Hasil Proses Belajar Mengajar. Bandung: Remaja Rosdakarya.

Sukmandari, D.G., \& Sukardiyono, T., (2017). Analisis Aplikasi Jadwal Perkuliahan
Berbasis Android. Jurnal Elinvo. 2(1). https://journal.uny.ac.id/index.php/elinvo/oai Widiadi, A.N., (2016). Pengembangan Aplikasi Ruang Kuliah Android (Arka) Untuk Matakuliah Penelitian Pendidikan Sejarah. Jurnal Pendidikan dan Sejarah. 10 (1). 111.

Yektyastuti, R., \& Ikhsan, J., (2016). Pengembangan Media Pembelajaran Berbasis Android Pada Materi Kelarutan Untuk Meningkatkan Performa Akademik Peserta Didik SMA. Jurnal Inovasi Pendidikan IPA. 5(1). 88-99. http://journal.uny.ac.id/index.php/jipi

Zahroh, S. M., (2014). Pengembangan Perangkat Pembelajaran Keterampilan Generik Komunikasi Negosiasi Siswa SMK dengan Metode 4-D. Jurnal Pendidikan Vokasi. 4 (3). $379-390$ 